\title{
Isolation of phosphate solubilizing Pseudomonas strains from apple rhizosphere in the Trans Himalayan region of Himachal Pradesh, India
}

\author{
Ranjna Sharma* Joginder Pal and Mohinder Kaur \\ Microbiology Section, Dept. of Basic Sciences, College of Forestry, \\ Dr. YS Parmar University of Horticulture \& Forestry, Nauni, Solan-173230 H.P. \\ *Indicates the corresponding author \\ Email: ranjnassharma@gmail.com
}

\begin{abstract}
Total fifteen phosphate solubilizing bacteria were isolated from rhizosphere soil of apple tree on Kings' B medium belonging to genus Pseudomonas spp. They were characterized on the basis of morphological and biochemical characteristics. Preliminary selection as phosphate solubilizing bacteria were done on the basis of formation of transparent zone around the colony on Pikovskaya's agar medium containing $0.5 \%$ triclcium phosphate (TCP). Maximum in vitro phosphate solubilization on Pikovskaya's agar plates after $72 \mathrm{~h}$ incubation at $28^{0} \mathrm{C}$ was shown by An-15-Mg (46 mm), whereas in case of broth, again this strain showed maximum tricalcium phosphate (TCP) solubilization $(76 \mu \mathrm{g} / \mathrm{ml})$. The $\mathrm{pH}$ of each inoculated broth was recorded daily and dropped significantly (pH 7.03.99). All the Pseudomonas isolates were further evaluated for overall plant growth promoting traits. Greatest siderophore activity was exhibited by An-14-Mg (71.23\%SU) followed by An-15-Mg (70.12 \%SU) which were statiscally at par with each other. Whereas, maximum IAA production was observed again in An-15-Mg (95 $\mu \mathrm{g} / \mathrm{ml})$. This isolate also showed the maximum production of HCN and ammonia. 16S rDNA and phylogenetic analysis showed that strain An-15-Mg exhibits 99\% level of similarity with Pseudomonas aeruginosa. Therefore, it was designated as Pseudomonas aeruginosa strain An-15-Mg. HPLC analysis showed that the Pseudomonas aeruginosa strain An-15-Mg produced maximum concentration of succinic acid, malonic, citric and malic acid with small amounts of schimic, quinic, tartaric, fumaric and lactic acids. The strain An-15-Mg possessed phosphate solubilization as major PGP trait along with different PGP traits. The potential phosphate solubilizing strain of Pseudomonas aeruginosa was reported first time as PGPR which lives in close association with apple tree without harming the plant, therefore could be used as a promising phosphate solubilizer and biofertilizer in apple crop grown in high hills of Himachal Pradesh.
\end{abstract}

Keywords: Apple rhizosphere, Pseudomonas, Insoluble phosphate, organic acids

\section{Authors contribution}

All authors made significant efforts towards the completion of this research work and preparation of manuscript timely. Author Ranjna Sharma has done collection of soil samples of apple tree from two districts, isolation and characterization of phosphate solubilizing Pseudomonas isolates and their screening for different PGPT's, phenotypic characteriazation, 16S rRNA analysis and statistical analysis. Author S P Singh has done HPLC analysis at their institute. Author Ankita has done sequence analysis and phylogenetic tree preparation. Author Mohinder Kaur is my mentor and generated idea regarding this work. She guided me in completing this work successfully as well as manuscript writing. 


\section{Introduction}

Phosphorus is an essential macronutrient required for the growth of the plants (Illmer and Schinner 1992). The phosphorus is applied to soil in the form of phosphatic fertilizers. $75-90 \%$ of phosphatic fertilizer when added to soil is precipitated by metal cation complexes (Stevenson 1986). It has been suggested that the accumulated phosphates in agricultural soils are sufficient to sustain maximum crop yields worldwide for about 100 years (Goldstein et al. 1993). The excessive application of P causes environmental and health problems. Therefore, it is necessary to have alternate solution to overcome this problem. Phosphate-solubilizing abilities of soil microorganisms have proved to be an economically sound alternative to the more expensive phosphatic fertilizers.

The organisms with phosphate-solubilizing potential increase the availability of soluble phosphate and can enhance plant growth by increasing the efficiency of biological nitrogen fixation or enhancing the availability of other trace elements such as iron, zinc, etc., and by production of plant growth-promoting regulators (Sattar and Gaur 1987; Kucey et al. 1989; Ponmurugan and Gopi 2006).

Solubilization and mineralization of phosphorus compounds by PGPR in soil seems to be one of the possible pathways by which plants takes inorganic phosphorus for their growth and development. 98\% of Indian soils are deficient in phosphorus, because the concentration of free phosphorus, the form available to plants even in fertile soils is generally not higher than $10 \mu \mathrm{M}$ even at pH 6.5 where it is most soluble (Narsian and Patel 2009).

Although microbial inoculants are in use for improving soil fertility during the last century, however, a meager work has been reported on P solubilization compared to nitrogen fixation. Microbial biomass assimilates soluble $\mathrm{P}$, and prevents it from adsorption or fixation (Khan and Joergensen 2009). Microorganisms enhance the $\mathrm{P}$ availability to plants by mineralizing organic $\mathrm{P}$ in soil and by solubilizing precipitated phosphates (Pradhan and Sukla 2005; Chen et al. 2006). These bacteria in the presence of labile carbon serve as a sink for $\mathrm{P}$ by rapidly immobilizing it even in low P soils (Bünemann et al. 2004).

Several machanisms may be involved for solubilization of insoluble phosphorus but, the major one is the action of organic acids synthesized by soil microorganisms (Mishra et al. 1990). Production of organic acids results in acidification of the microbial cell and its surroundings. Consequently, inorganic phosphorus (Pi) may be released from a mineral phosphate by proton substitution for $\mathrm{Ca}^{+2}$ (Goldstein 1994).

Fluorescent Pseudomonas sp. are effective phosphate solubilizers which directly or indirectly promote the growth of plants by increasing the concentration of available nutrients and antibiosis. Therefore, the aim of the present study was to explore the potential phosphate solubilizing PGP Pseudomonas sp. associated with apple tree in temperate and sub temperate zones of Himachal Pradesh. All the strains were tested for in vitro production of phosphate solubilization and other PGP activities. The potential phosphate solubilizing Pseudomonas strain has been used for organic acid estimation through HPLC and its molecular analysis was done.

\section{Material and Methods}

\section{Collection of Soil Samples}

Soil samples were collected at $5-15 \mathrm{~cm}$ depth in the area of tree basin. A total of Twelve composite samples of soil were drawn from normal (Seven) and diseased sites (five) of apple from Shimla and Kullu Districts of Himachal Pradesh, India and used for isolation of phosphate solubilizing bacterial (PSB) population. Samples were immediately stored at $4^{0} \mathrm{C}$ in plastic bags loosely tied to ensure sufficient aeration and to prevent moisture loss until isolation of bacterial community. Isolates from normal sites were designated as An whereas isolates from sick site as Ar.

\section{Isolation of phosphate solubilizing rhizobacteria}


Phosphate solubilizing rhizobacteria were isolated from collected soil samples of apple trees by serial dilution using a standard spread plate technique on Pikovskaya's (PVK) medium (Pikovskaya 1948) supplemented with tri-calcium phosphate (TCP, $0.5 \%)$ as an insoluble inorganic phosphate source. PSB were expressed as colony forming unit (CFU) per gram of dry soil weight. These isolated colonies were maintained on PVK medium with $30 \%$ glycerol on cryopreservation tubes at $-20^{\circ} \mathrm{C}$ for further study.

\section{Phenotypic Identification}

Further identification of Phosphate solubilizing rhizobacterial population isolated from collected soil samples of apple trees were done on the basis of Gram staining, spore staining, cellular morphology and other biochemical tests as per their genera as prescribed in Bergey's Manual of Systematic Bacteriology. The most predominant rhizobacterial isolates showing greenish/yellowish fluorescent pigments at $302 \mathrm{~nm}$ wavelength in BIORAD gel doc system XR were assumed to be Pseudomonas sp.

\section{Phosphate Solubilization}

All the isolates were grown in PVK broth $(10 \mathrm{ml})$ supplemented with $0.5 \%$ tri-calcium phosphate (TCP) for 72 hours at $28 \pm 2^{\circ} \mathrm{C}$ under shake conditions $(100 \mathrm{rpm})$. Supernatant was prepared by centrifugation of culture at 12,000 rpm for 20 minutes and stored at $4^{\circ} \mathrm{C} .100 \mu \mathrm{l}$ cell free supernatant of each isolate was applied to $10 \mathrm{~mm}$ wells of pre poured sterilized PVK agar plates (Pikovsakaya 1948). Plates were incubated at $28 \pm 2^{\circ} \mathrm{C}$ for three days and observed for $\mathrm{P}$ solubilisation in the form of clear zone produced around the well. Further quantitative estimation of phosphorus was done in PVK broth by the vanadomolybdate method (Sundara Rao and Sinha 1963). Change in $\mathrm{pH}$ of the culture broth was recorded by $\mathrm{pH}$ metre equipped with a glass electrode.

\section{Screening of phosphate solubilizing bacteria for other plant growth promoting traits}

\section{Siderophore activity}

Siderophore production was observed in terms of reduction in blue color as per cent siderophore units (\% SU) by the method (Schwyn and Neilands 1987).

$\% \mathrm{SU}=\quad \begin{array}{cc}\mathrm{Ar}-\mathrm{As} \\ \mathrm{Ar}\end{array}$

$\mathrm{Ar}=\mathrm{Absorbance}$ of reference at $630 \mathrm{~nm}, \mathrm{As}=\mathrm{Absorbance}$ of supernatant at $630 \mathrm{~nm}$

\section{IAA production}

Quantitative estimation of IAA was carried out by the method described by Gordon and Paleg (1957).

\section{HCN and Ammonia production}

Hydrogen cyanide $(\mathrm{HCN})$ production was determined on King's B agar medium supplemented with 4.0g/l glycine after 3 days of incubation at $28 \pm 2^{\circ} \mathrm{C}$ (Bakker and Schippers 1987). Whereas ammonia production was determined by the method given by Lata and Saxena 2003.

\section{Identification of potential phosphate solubilizing Pseudomonas strain and its phylogenetic analysis}

The rhizobacterial isolate that was identified as the potential phosphate solubilizing Pseudomonas isolate during in vitro evaluation was characterized to species level assessed for organic acid production by HPLC. Bacterial genomic DNA was isolated by using DNA purification kit (Banglore Genei Pvt. Ltd., India) as per the manufacturer's instructions. Pseudomonas specific primer set (forward 5' GGTCTGAGAGGATGATCAGT 3' and reverse 5' TTAGCTCCACCTCGCGGC3') was used to amplify $16 \mathrm{~S}$ rDNA of potential phosphate solubilizer. PCR reactions were carried out in $20 \mathrm{ml}$ reaction volume containing ,50 ng of template DNA, 20pmoles of each primer, $0.2 \mathrm{mM}$ dNTPs and $1 \mathrm{U}$ Taq polymerase in $1 \times$ PCR buffer. Reactions were performed under following conditions: initial denaturation at $94^{\circ} \mathrm{C}$ for $30 \mathrm{~s}, 588 \mathrm{C}$ for $1 \mathrm{~min}$. followed by 35 cycles of $92^{\circ} \mathrm{C}$ for $1 \mathrm{~min}$., annealing at $55^{\circ} \mathrm{C}$ for $1 \mathrm{~min}$ $30 \mathrm{~s}$ and final extension at $72^{\circ} \mathrm{C}$ for $10 \mathrm{~min}$. The amplified PCR product was separated by gel electrophoresis on $1.0 \%$ 
(w/v) agarose gel. The purified fragment was sequenced from Xcleris lab, Ahmadabad, India using gene specific primers (both forward and reverse primers). The sequence obtained were subjected to database search using BLAST nsuite (NCBI). Based on 16S rRNA gene sequences, phylogenetically related bacteria were aligned using a BLAST search (Altschul et al. 1997). Multiple alignment with sequences of related taxa of the genus Pseudomonas was implemented using CLUSTAL W (version 1.6). The neighbour-joining phylogenetic tree was constructed and analyzed using MEGA 6 software. The topology of the phylogenetic tree was evaluated by the bootstrap resampling method of Felsenstein (1985) with 100 replicates. The sequence was submitted to NCBI GenBank database and accession number was assigned.

For the analysis of organic acids, Pseudomonas strain An-15-Mg was grown and multiplied in PVK liquid medium. A $2 \mathrm{ml}$ of three day old cell free supernatant of Pseudomonas strain An-15-Mg obtained after solubilization of tri-calcium phosphate $(0.5 \%)$ was homogenized using a vortex mixer and then centrifuged at $10,000 \times \mathrm{g}$ at $4^{\circ} \mathrm{C}$ for $10 \mathrm{~min}$. The supernatant was filtered through $0.2 \mu \mathrm{m}$ syringe filter and $20 \mu \mathrm{l}$ filtrate was injected into HPLC-MS/MS system. The samples in autosampler were kept at $4^{\circ} \mathrm{C}$.The organic acids were separated by using a Hi Plex H $(7.7 \times 300 \mathrm{~mm} \times 8 \mu \mathrm{m}$ ), (Agilent Technologies Pvt. Ltd., Chandigarh, India) column and a guard column (Hi-Plex H $3 \times 5 \mathrm{~mm} \times 8 \mu \mathrm{m}$ ) (Agilent Technologies) maintained at $60^{\circ} \mathrm{C}$ at a flow rate of $0.6 \mathrm{~mL} / \mathrm{min}$. The samples were run isocratically using $0.1 \%$ formic acid in water for $20 \mathrm{~min}$. The MS/MS analysis was performed with a hybrid triple quadrupole/ion trap mass spectrometer, QTRAP 5500 (ABSciex India Pvt. Ltd., Gurgaon, India). The mass spectra were acquired using TurbolonSpray ionization in negative ion mode and scheduled MRM using analyst software.

The compound-dependent MS parameters were determined by infusion of each compound. The curtain gas was adjusted to $30 \mathrm{psi}$. The ion spray voltage, ion source gas 1 , and ion source gas 2 were $-4.5 \mathrm{kV}, 50 \mathrm{psi}$, and 50 psi, respectively. The temperature of the source was fixed to $550^{\circ} \mathrm{C}$. The authentic standards of organic acids were used for preparation of calibration curve. The organic acids in the samples were determined by comparing the retention times and peak areas of chromatograms with the standards for malic acid, malonic acid, citric acid, tartaric acid, succinic acid, formic acid, lactic acid, quinic acid and schimic acid. The quantification of organic acids was conducted using MultiQuant software.

\section{Statistical Analysis}

Experimental data were analysed using standard analysis of variance (ANOVA) followed by Duncan's multiple comparison tests $(\mathrm{p}<0.05)$. Standard errors were calculated for all mean values. Arcsine transformation was applied to data expressed in percentage.

\section{Results}

\section{Morphological and biochemical characteristics of phosphate solubilizing bacterial isolates}

The phosphate solubilizing bacterial isolates were isolated from collected soil samples of both the districts on Pikovskaya's agar medium. The bacterial colonies were circular/irregular in shape, raised elevation, entire edge with transparent opacity producing bluish/greenish to brown pigment on nutrient agar plates. They were identified biochemically as positive for catalase, oxidase and oxidative metabolism, whereas negative for Grams staining, tween 80 hydrolysis and spore staining. $80 \%$ of the isolates were positive for denitrification test, whereas $66.67 \%$ isolates were positive for Gelatin liquefaction test. Fifteen bacterial isolates showed optimum growth at $28^{\circ} \mathrm{C}$ on King's B medium (Table 1). On the basis of physiological and biochemical characteristics, the P-solubilizing bacteria were identified as Pseudomonas spp.

\section{Screening of phosphate solubilizing bacteria for plant growth promoting traits (PGPTs)}

All the fifteen Pseudomonas isolates were screened for plant growth promoting traits (Table 2). The Pseudomonas isolate An-15-Mg showed highest P-solubilization both in plate assay $(46 \mathrm{~mm})$ and liquid assay method $(79 \mu \mathrm{g} / \mathrm{ml})$ simultaneousely maximum decrease in the $\mathrm{pH}$ of the medium (pH 7.0-3.99). In vitro evaluation of biocontrol 
features showed that highest per cent siderophore unit (\% SU) was shown by the isolate An-14-Mg (71.23\%SU) followed by An-15-Mg (70.12\%SU) which were significantly at par with each other after $72 \mathrm{~h}$ of incubation at $28^{\circ} \mathrm{C}$. Significantly higher auxin production was exhibited by two Pseudomonas isolate An-7-Mg and An-15-Mg (95 $\mu \mathrm{g} / \mathrm{ml}$ each). Greatest HCN production was exhibited by isolate An-15-Mg (++++) followed by An-7-Mg (+++), whereas maximum ammonia production was obtained in four Pseudomonas isolates Ar-1-Mg, Ar-11-Mg, An-14$\mathrm{Mg}$ and An-15-Mg (++++).

\section{Phylogenetic analysis of potential Pseudomonas strain An-15-Mg by 16S rDNA sequence analysis}

The Pseudomonas strain An-15-Mg was found to be the most effective phosphate solubilzer under in vitro conditions along with other plant growth promoting traits. Therefore the strain $\mathrm{An}-15-\mathrm{Mg}$ was identified to the species level by $16 \mathrm{~S}$ rDNA sequence analysis. The $16 \mathrm{~S}$ rDNA fragment was successfully amplified using Pseudomonas specific primers and sequenced. Both the forward and reverse sequences so obtained were corrected, and unreadable and ambiguous sequences were deleted. Finally a complete sequence of 787bp was obtained. Sequence analysis revealed that isolate An-15-Mg showed 99\% homology with Pseudomonas aeruginosa (CP017353). A phylogenetic tree also verified the identity of strain An-15-Mg as P. aeruginosa because the isolate was closely clustered with $P$. aeruginosa (CP015002) high boot strap value of 65\% (Figure 2). The sequence of strain An-15-Mg was deposited in NCBI Genbank under accession number KJ500026 and was designated as Pseudomonas aeruginosa strain An-15-Mg.

\section{Production of different organic acids}

HPLC-MS/MS system analysis of culture filtrate showed the presence of multiple organic acids during the solubilization of tricalcium phosphate. A decrease in the $\mathrm{pH}$ of the growth medium was observed after $72 \mathrm{~h}(\mathrm{pH} 7.0$ $\mathrm{pH}$ 3.99). Among the different authentic organic acids used for the comparison, production of succinic acid (1.65 $\mu \mathrm{g} / \mathrm{ml})$ was higher followed by malonic acid $(0.390 \mu \mathrm{g} / \mathrm{ml})$, citric acid $(0.378 \mu \mathrm{g} / \mathrm{ml})$ and malic acid $(0.162 \mu \mathrm{g} / \mathrm{ml})$ given in Table 3 and Figure 2. Quinic acid $(0.089 \mu \mathrm{g} / \mathrm{ml})$, lactic acid $(0.086 \mu \mathrm{g} / \mathrm{ml})$, tartaric acid $(0.065 \mu \mathrm{g} / \mathrm{ml})$ and schimic acid $(0.020 \mu \mathrm{g} / \mathrm{ml})$ and fumaric acid $(0.013 \mu \mathrm{g} / \mathrm{ml})$ were produced in small amount during the solubilization of tricalcium phosphate. 
Table:1 Physiological and biochemical characteristics of bacterial isolate from rhizosphere soil of normal and sick sites of apple

\begin{tabular}{|c|c|c|c|c|c|c|c|c|c|c|}
\hline \multirow{2}{*}{$\begin{array}{l}\text { District } \\
\text { Shimla }\end{array}$} & \multirow{2}{*}{\begin{tabular}{|l|} 
Site \\
Normal \\
\end{tabular}} & \multirow[t]{2}{*}{ Isolate } & \multicolumn{7}{|c|}{ Characteristics } & \multirow{2}{*}{$\begin{array}{l}\text { Growth } \\
\text { (King's B } \\
\text { agar) } \\
28^{0} \mathrm{C}\end{array}$} \\
\hline & & & Gram Staining & $\begin{array}{l}\text { Tween } 80 \\
\text { Hydrolysis }\end{array}$ & $\begin{array}{l}\text { Metabolism } \\
\text { (oxidative) }\end{array}$ & $\begin{array}{l}\text { Denitrifi- } \\
\text { Cation }\end{array}$ & Oxidase & Caalase & $\begin{array}{l}\text { Gelatin } \\
\text { Liquifaction }\end{array}$ & \\
\hline & & An-2-Mg & - & - & + & - & + & + & - & + \\
\hline & & An-3-Mg & - & - & + & + & + & + & + & + \\
\hline & & An-4-Mg & - & . & + & + & + & + & + & + \\
\hline & & An-5-Mg & - & - & + & - & + & + & - & + \\
\hline & & An-6-Mg & - & - & + & - & + & + & - & + \\
\hline & & An-7-Mg & - & - & + & + & + & + & + & + \\
\hline & & An-9-Mg & - & - & + & + & + & + & + & + \\
\hline & & An-10-Mg & - & - & + & + & + & + & + & + \\
\hline & Sick & Ar-1-Mg & - & - & + & + & + & + & + & + \\
\hline & & Ar-8-Mg & - & - & + & + & + & + & - & + \\
\hline & & Ar-11-Mg & - & - & + & + & + & + & - & + \\
\hline Kullu & Normal & An-12-Mg & - & - & + & + & + & + & + & + \\
\hline & & An-13-Mg & - & - & + & + & + & + & + & + \\
\hline & & An-14-Mg & - & - & + & + & + & + & + & + \\
\hline & & An-15-Mg & - & - & + & + & + & + & + & + \\
\hline
\end{tabular}

(+) indicates positivity and (-) negativity of test 
Table 2 Different plant growth promoting traits of P-solubilizing Pseudomonas isolates

\begin{tabular}{|c|c|c|c|c|c|c|c|}
\hline \multirow[t]{3}{*}{ Isolates } & \multicolumn{2}{|c|}{ P-solubilization } & \multirow[t]{3}{*}{ Final $\mathrm{pH}$} & \multirow{3}{*}{$\begin{array}{l}\text { Siderophore Production } \\
(\% \mathrm{SU})\end{array}$} & \multirow[t]{3}{*}{ Auxins $(\mu \mathrm{g} / \mathrm{ml})$} & \multirow{2}{*}{\multicolumn{2}{|c|}{\begin{tabular}{l|l} 
HCN Production & Ammonia production \\
Change of color (yellow to brown)
\end{tabular}}} \\
\hline & \multirow{2}{*}{$\begin{array}{l}\text { (mm } \\
\text { diameter) }\end{array}$} & \multirow{2}{*}{$(\mu \mathrm{g} / \mathrm{ml})$} & & & & & \\
\hline & & & & & & Paper strip & Culture broth \\
\hline An-2-Mg & $22 \pm 0.90 \mathrm{kl}$ & $17.00 \pm 2.34 \mathrm{n}$ & 5.20 & $45.06(42.15)$ & $81 \pm 1.67 f$ & ++ & +++ \\
\hline An-3-Mg & $21 \pm 0.17 i$ & $28.00 \pm 1.00$ efghijk & 4.92 & $46.60(43.03)$ & $73 \pm 1.29 \mathrm{~h}$ & ++ & +++ \\
\hline An-4-Mg & $32 \pm 0.60 \mathrm{~h}$ & $29.00 \pm 0.88$ efhij & 4.90 & $42.59(40.92)$ & $68 \pm 2.00 \mathrm{i}$ & ++ & +++ \\
\hline An-5-Mg & $20 \pm 0.21 \mathrm{i}$ & $20.00 \pm 3.80 \mathrm{n}$ & 5.09 & $38.58(38.38)$ & $66 \pm 0.22 \mathrm{ij}$ & ++ & +++ \\
\hline An-6-Mg & $26 \pm 1.00 \mathrm{j}$ & $34.00 \pm 3.00 \mathrm{cde}$ & 4.56 & $44.14(41.61)$ & $56 \pm 2.00 \mathrm{im}$ & ++ & +++ \\
\hline An-7-Mg & $20 \pm 0.38 \mathrm{i}$ & $26.00 \pm 1.00 \mathrm{ijklm}$ & 4.99 & $44.19(41.64)$ & $95 \pm 2.69 \mathrm{ab}$ & +++ & +++ \\
\hline An-9-Mg & $42 \pm 0.31 \mathrm{bcd}$ & $27.00 \pm 0.87 \mathrm{hijkl}$ & 5.01 & $37.65(37.83)$ & $89 \pm 1.00 \mathrm{c}$ & ++ & +++ \\
\hline An-10-Mg & $40 \pm 0.45 \mathrm{cde}$ & $29.00 \pm 2.75 \mathrm{efgh}$ & 4.92 & $38.27(38.20)$ & $43 \pm 2.00 \mathrm{o}$ & ND & ++ \\
\hline Ar-1-Mg & $40 \pm 1.00 \mathrm{cdef}$ & $30.00 \pm 5.00 \mathrm{defg}$ & 4.88 & $49.69(44.80)$ & $55 \pm 0.50 \mathrm{imn}$ & + & ++++ \\
\hline Ar-8-Mg & $23 \pm 1.00 \mathrm{k}$ & $32.00 \pm 2.00 \mathrm{def}$ & 4.82 & $41.67(40.18)$ & $57 \pm 1.00 \mathrm{i}$ & ND & ++ \\
\hline Ar-11-Mg & $32 \pm 0.56 \mathrm{hi}$ & $29.00 \pm 4.00$ efghi & 4.81 & $38.89(3.56)$ & $80 \pm 1.50 \mathrm{fg}$ & ++ & ++++ \\
\hline An-12-Mg & $43 \pm 0.57 b$ & $38.00 \pm 1.72 \mathrm{c}$ & 4.25 & $56.42(48.66)$ & $87 \pm 1.92 \mathrm{~cd}$ & ++ & +++ \\
\hline An-13-Mg & $37 \pm 1.00 \mathrm{~g}$ & $37.00 \pm 1.91 \mathrm{~cd}$ & 4.28 & $67.04(54.94)$ & $85 \pm 1.00 \mathrm{de}$ & ND & +++ \\
\hline An-14-Mg & $42 \pm 0.76 b c$ & $47.00 \pm 1.00 \mathrm{~b}$ & 4.10 & $71.23(57.54)$ & $72 \pm 1.00 \mathrm{i}$ & ++ & ++++ \\
\hline An-15-Mg & $46 \pm 0.24 \mathrm{a}$ & $76.00 \pm 1.66 \mathrm{a}$ & 3.99 & $70.12(56.84)$ & $95 \pm 2.05 \mathrm{a}$ & ++++ & ++++ \\
\hline
\end{tabular}

Values are the mean \pm SD. Mean values in each column followed by the same letter do not differ significantly at $p \# 0.05$. ND- Not detected 
bioRxiv preprint doi: https://doi org/10.1101/193672; this version posted September 25, 2017. The copyright holder for this preprint (which was not certified by peer review) is the author/funder, who has granted bioRxiv a license to display the preprint in perpetuity. It is made available under aCC-BY 4.0 International license.

Table 3 Organic acid production during solubilization of phosphate substrate (TCP) by

Pseudomonas aeruginosa strain An-15-Mg after three days of incubation at $28 \pm 2^{\circ} \mathrm{C}$

\begin{tabular}{|l|l|l|l|l|l|l|l|l|l|}
\hline \multirow{2}{*}{$\begin{array}{l}\text { P- } \\
\text { source }\end{array}$} & \multicolumn{9}{|c|}{ Organic acids $(\boldsymbol{\mu g} / \mathbf{m l})$} \\
\cline { 2 - 10 } & Succinic & Fumaric & Tartaric & Citric & Malonic & Malic & Quinic & Schimic & Lactic \\
\hline TCP & 1.65 & 0.013 & 0.065 & 0.378 & 0.390 & 0.162 & 0.089 & 0.020 & 0.086 \\
\hline
\end{tabular}

values are means of three replicates 


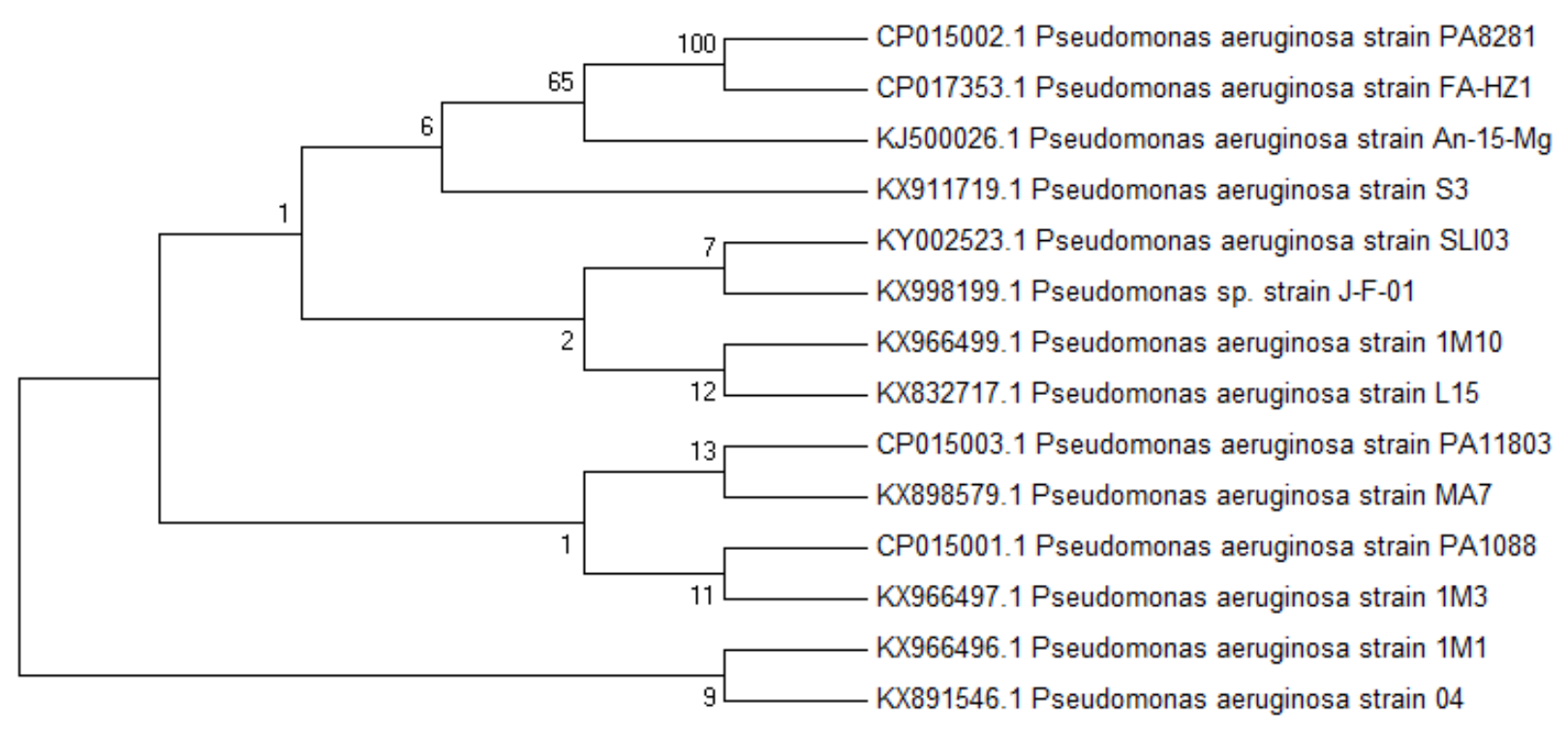

Figure 1. Neighbour-joining phylogenetic dendogram based on 16S rRNA sequences showing relationships between isolate An-15-Mg and related taxa.

A

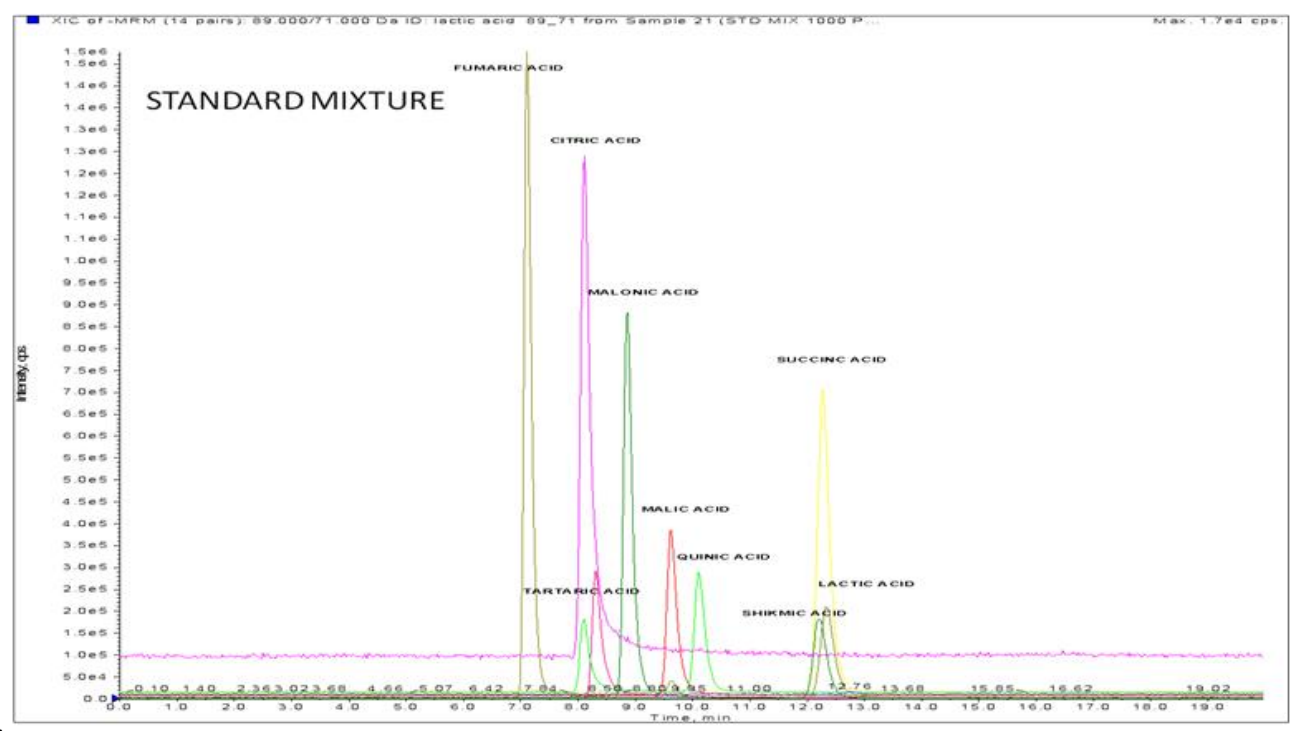


bioRxiv preprint doi: https://doi.org/10.1101/193672; this version posted September 25, 2017. The copyright holder for this preprint (which was not certified by peer review) is the author/funder, who has granted bioRxiv a license to display the preprint in perpetuity. It is made available under aCC-BY 4.0 International license.

B

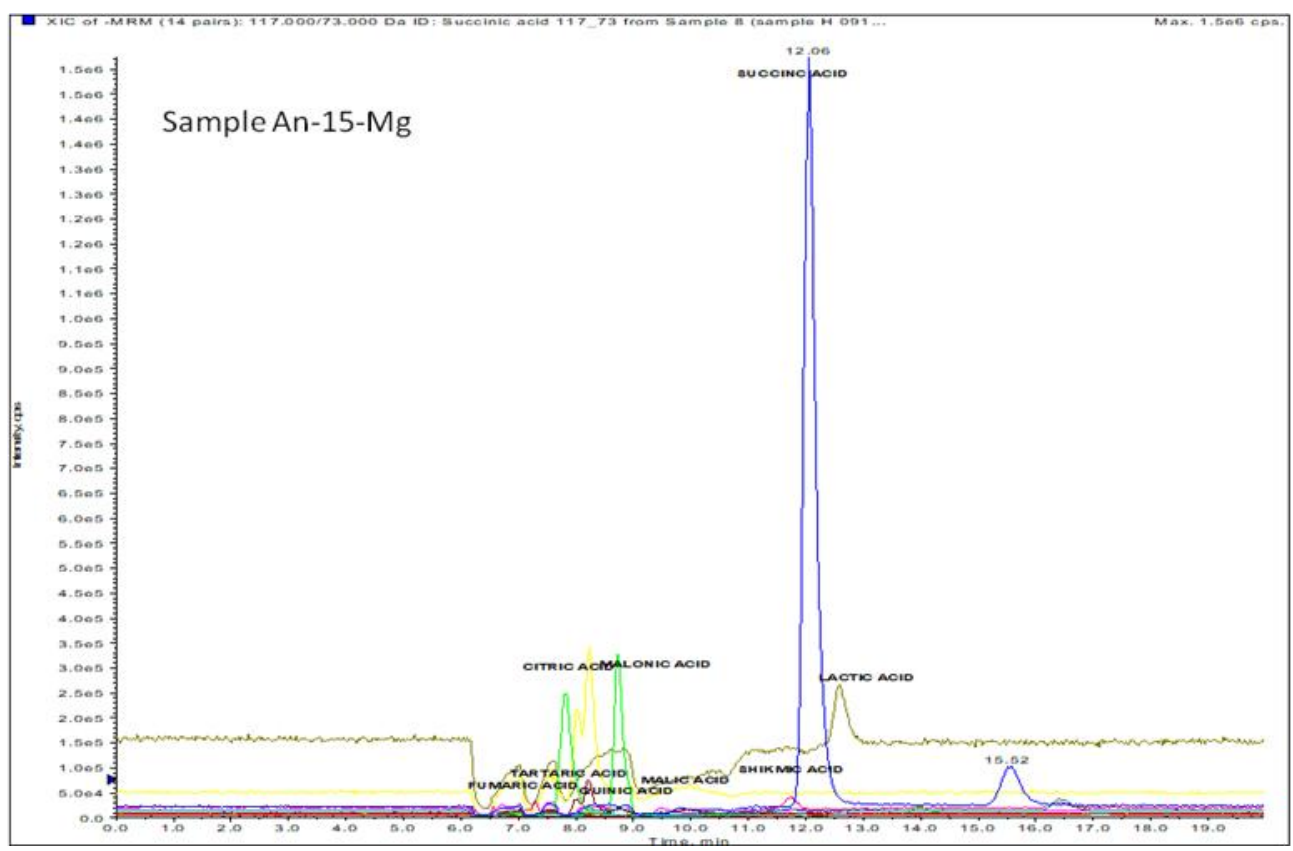

Figure 2 HPLC chromatograms of authentic standards (A) and different organic acids produced by potential P-solubilizing Pseudomonas aeruginosa strain An-15-Mg (B) 


\section{Discussion}

In the present study, total fifteen phosphate solubilizing plant growth promoting bacteria belonging to genus Pseudomonas spp. were isolated from healthy and sick sites of apple tree on King's B medium from Shimla and Kullu districts of Himachal Pradesh. The preliminary selection as phosphate solubilizer were done on Pikovskaya's agar medium. The yellow coloured colonies surrounded by transparent halo were selected and purified on the same medium. They all belongs to Pseudomonas spp. isolates on the basis of morphological and biochemical characterization (Table 1). Pseudomonas spp. a well-known plant-associated bacteria and effective root colonizer detected in this study as abundant members of the cultivable P-solubilizing PGPR community. This is most likely due to the microbial community composition of the study sites.

Phosphate solubilization is the important mechanism of plant growth promotion. Insufficient availability of phosphorus limits the growth of plants. The low solubility of tricalcium phosphate, hydroxyapatite and aluminum phosphate causes low availability of phosphorus in apple orchards. All the Pseudomonas isolates were screened for phosphate solubilization and other plant growth promoting traits (PGPTs). They all produce atleast one or more plant growth promoting traits. Maximum production of phosphate solubilization under plate and liquid assay method was shown by An-15-Mg (Table 2).

Park et al. 2009 showed that Pseudomonas fluorescens RAF15 produced a wide range of secondary metabolites like siderophore, HCN, and IAA which showed potential efficacy not only against phytopathogenic fungi but also promote plant growth. The role of siderophore in biocontrol of several fungal phytopathogens has been reported (Scher and Baker 1982). Several plant growth-promoting rhizobacteria are known to secrete IAA into culture media, and have been shown to stimulate plant growth (Gaudin et al. 1994). In addition to insoluble P solubilizaion by producing different organic acids substantial production of siderophore, HCN, ammonia and IAA by potential phosphate solubilizing strain Pseudomonas aeruginosa An-15-Mg clearly suggests its use as biofertilizer and phosphate solubiizer.

Several mechanisms have been proposed for the suppression of phytopathogens by antagonistic bacteria, including production of antibiotics, siderophore and lytic enzymes such as amylase, chitinase, protease and cellulase (Amaresan et al. 2012).

Multiple biocontrol mechanisms have been implicated in the suppression of fungal root diseases by biocontrol species of Bacillus. It has been strongly suggested that the main success of a biocontrol agent is largely attributable to multifunctional biocontrol traits (Vassilev et al. 2006).

$16 \mathrm{~S}$ rRNA gene sequence analysis is an authentic technique used to study bacterial isolate at species level and allows their identification as well as prediction of phylogenetic relationship (Naz and Bano 2010). Sequence analysis of potential phosphate solubilizing Pseudomonas isolate An-15-Mg revealed that it showed $99 \%$ similarity with Pseudomonas aeruginosa (CP017353). A phylogenetic tree also verified the identity of strain An-15-Mg as $P$. aeruginosa because the isolate was closely clustered with P. aeruginosa (CP017353) high boot strap value 65\% (Figure 1).

Exudation of nutrients from roots of apple tree might exert a selective pressure on the proliferation of plant growth promoting microbial community such as Pseudomonas and Bacillus. Selective pressure through different host plants has been suggested earlier by Siciliano and Germida 1999, as observed in the present study.

HPLC analysis of $72 \mathrm{~h}$ old culture supernatant of Pseudomonas aeruginosa mainly produced succinic, malonic, citric, malic, oxalic acids with small amount of lactic, schimic, tartaric and quinic acids in $72 \mathrm{~h}$ old culture supernatant containing glucose as major substrate (Figure 2), Simultaneousely there were observed a decrease in the $\mathrm{pH}$ of the medium from $\mathrm{pH}$ 7.0-3.99. Goldstein et al. 1993, showed that organic acids like glycolic, gluconic, 
succinic, oxalic, citirc and malonic acids have been identified in phosphate solubizers namely Bacillus firmus, Pseudomonas cepacia and Pseudomonas sp. A decline in the $\mathrm{pH}$ of the medium during solubilization of phosphate substrates suggested the secretion of organic acids by Acinetobacter rhizosphaerae BIHB 723 as reported for other bacteria (Chen et al. 2006). Gulati et al. 2010, showed that the strain Acinetobacter rhizosphaerae BIHB 723 produced different organic acids during the solubilization of phosphate substrates explicating the influence of substrate on the production of organic acids i.e oxalic, gluconic, 2-Keto gluconic, lactic, formic and malic acid. The higher solubilization of TCP being due to its amorphous nature and is more facile to solubilization.

\section{Conclusion}

Fluorescent Pseudomonas sp. are commonly found in rhizosphere of different crops. Potential phosphate solubilizing Pseudomonas aeruginosa strain An-15-Mg isolated from the rhizospheric soil of apple tree could be used as a potential phosphate solubilizer in agricultural environments. Because of the innate potential of producing siderophore, IAA, HCN and ammonia, Pseudomonas aeruginosa strain An-15-Mg could be used as a biofertilizer as well as a potential biocontrol agent. In vitro production of different PGPTs cannot always be reproduced under field conditions. Therefore, field evaluation of this strain as effective plant growth promoting bacterium is still under process.

\section{Acknowledgement}

The present study was supported by funds from the Department of Science and Technology, New Delhi and Department of Basic Sciences, Dr. YSP UHF, Nauni, Solan Himachal Pradesh, India. 


\section{References}

Altschul SF, Thomas LM, Alejandro AS, Jinghui Z (1997) Gapped BLAST and PSIBLAST: a new generation of protein database search programs. Nucl Acid Res. 25:3389-3402. doi:10.1093/ nar/25.17.3389.

Amaresan N, Jayakumar V, Kumar Krishna, Thajuddin N (2012) Endophytic bacteria from tomato and chilli, their diversity and antagonistic potential against Ralstonia solanacearum. Arch Phytopathol Plant Protect. 45:344-355. doi:10.1080/03235408.2011.587273.

Bakker AW, Schippers B (1987) Microbial cyanide production in the rhizosphere in relation to potato yield reduction and Pseudomonas spp. mediated plant growth-stimulation. Soil Biol Biochem. 19:451-457. doi:10.1016/0038-0717(87)90037-X.

Bünemann E K, Steinebrunner F, Smithson PC, Frossard E, Oberson A (2004) Phosphorus dynamics in a highly weathered soil as revealed by isotopic labelling techniques. Soil Sci Soci Am Jour 68: 1645-1655

Chen YP, Rekha PD, Arun A B, Shen FT, Lai WA, Young CC (2006) Phosphate solubilizing bacteria from subtropical soil and their tricalcium phosphate solubilizing abilities. Appl Soil Ecol 34: 33-41

Felsenstein J (1985) Confidence limits on phylogenies: an approach using the bootstrap. Evol. 39:783-791. doi: $10.2307 / 2408678$

Gorden, S.A. and L.P. Paleg (1957) Quantitative measurement of indole acetic acid. Physiol. Plant., 10: 347-348.

Gaudin, V., Vrain, T. and Jouanin, L. (1994) Bacterial genes modifying hormonal balances in plants. Plant Physiol Biochem 32, 11-29.

Lata and Saxena A K (2003) Characterization of plant growth promoting rhizobacteria. In: Training manual on biofertilizer technology. Saxena A K (ed.). Delhi: IARI. pp. 24-25

Goldstein AH (1994) Involvement of the quinoprotein glucose dehydrogenase in the solublization of exogenous phosphates by gram negative bacteria. In: Gorini A, Torrini A, Yagil E, Silver S (eds.) Phosphate in Microorganisms: Cellular and Molecular biology. ASM Press Washington D C pp 197-203.

Goldstein AH, Rogers RD, Mead G (1993) Mining by microbe. Biotechnol 11: 1250-1254

Gulati A, Sharma N, Vyas P, Sood S, Rahi P, Pathania V, Prasad R (2010) Organic acid production and plant growth promotion as a function of phosphate solubilization by Acinetobacter rhizosphaerae strain BIHB 723 isolated from the cold deserts of the trans-Himalayas. Arch Microbiol 192: 975-983

Khan KS, Joergensen RG (2009) Changes in microbial biomass and P fractions in biogenic household waste compost amended with inorganic P fertilizers. Biores Technol 100: 303-309

Kucey RM N, Janzen HH, Legget ME (1989) Microbial mediated increase in plant available phosphorus. Adv Agronom 42: 199-228

Mishra AK, Bhattacharya P, Chakrabartty PK (1990) Solubilization of rock phosphate by Rhizobium and Bradyrhizobium. Jr Gen Appl Microbiol 36: 81-92

Narsian V, Patel HH (2009) Relationship of physicochemical properties of rhizosphere soils with native population of mineral phosphate solubilizing fungi. Ind Jr Microbiol 49: 60-67

Naz I, Bano A. (2010) Biochemical, molecular characterization and growth promoting effects of phosphate solubilizing Pseudomonas sp. isolated from weeds grown in salt range of Pakistan. Plant Soil. 334:199-207. doi:10.1007/s11104-010-0372-8.

Park KH, Lee CY, Son H J (2009) Mechanism of insoluble phosphate solubilization by Pseudomonas fluorescens RAF15 isolated from ginseng rhizosphere and its plant growth-promoting activities. Lett Appl Microbiol 49:222228. doi:10.1111/j.1472-765X.2009.02642.x

Pikovsakaya RE (1948) Mobilization of phosphorus in soil in connection with vital activity of some microbial species. Microbiologia 17: 362-370 
Ponmurugan P, Gopi C (2006) In-vitro production of growth regulators and phosphatase activity by phosphate solubilizing bacteria. Af Jr Biotechnol 5(4): 348-350

Pradhan N, Sukla LB (2005) Solubilization of inorganic phosphate by fungi isolated from agriculture soil. Af Jr Biotechnol 5: 850-854

Sattar MA, Gaur AC (1987) Productions of auxins and gibberellins by phosphate dissolving microorganisms. Zbl. Mikrobiol 142: 393-395

Scher FM, Baker R (1982) Effect of Pseudomonas putida and a synthetic iron chelator on induction of soil suppressiveness to Fusarium wilt pathogens. Phytopathol 72, 1567-1573

Siciliano SD, Germida JJ (1999) Taxonomic diversity of bacteria associated with the roots of fieldgrown transgenic Brassica napus cv. Quest, compared to the non-transgenic b. Napus cv. Excel and b. Rapa cv. Parkland. FEMS Microbiol Ecol 29:263-272. doi:10.1111/j.1574-6941.1999. tb00617.x.

Stevenson E J (1986) Cycles of soil. John Wiley and Sons, New York

Schwyan B, Neilands J B (1987) Universal chemical assay for the detection and determination of siderophores. Analy Biochem 28(8): 751-759

Sundara Rao WVB, Sinha MK (1963) Phosphate dissolving microorganisms in the soil and rhizosphere. Indian J Agric Sci 33:272-278

Vassilev N, Vassileva M, Nikolaeva I (2006) Simultaneous P-solubilizing and biocontrol activity of microorganisms: potentials and future trends. Appl Microbiol Biotechnol 71:137-144. doi:10. 1007/s00253-0060380-z.

Illmer PA, Schinner F (1992) Solubilization of inorganic phosphates by microorganisms isolated from forest soil. Soil Biol Biochem 24: 389-395. 10.1016/0038-0717(92)90199-8 